\author{
山野 優 子*, 徳 武 智 子*, 香川 順* \\ 石 津 登 子**
}

\title{
SUBJECTIVE SYMPTOMS AND BLOOD FINDINGS IN PAINTERS EXPOSED TO ORGANIC SOLVENTS
}

\author{
Yuko Yamano,* Tomoko TOKUTAKE, ${ }^{*}$ Jun KagAwA* \\ and Sumiko ISHIZU**
}

\begin{abstract}
Subjective symptoms and blood findings were studied in 16 construction workers and 30 vehicle repairmen using organic solvent and compared to 30 workers who were not exposed to organic solvents.

A statistically significant increase was observed in the prevalence of subjective symptoms, serum phospholipid, lipoprotein fraction and $\mathrm{IgE}$ level in construction workers and vehicle repairmen.

A statistically significant decrease in neutrophils function was observed in construction workers.

Key words : organic solvent; construction worker; neutrophils function; serum lipoprotein; $\operatorname{IgE}$
\end{abstract}

\section{I.はじめに}

等装作業は多くが下請け作業者によって行われ，作業 者に対する十分な衛生教育もなされない状態で実施され ているのではないかと思われる゙。

著者らは，某建設会社の下請けの塗装作業をしている 建設労働者，また，環境条件，作業条件の比較的整備さ れたところで塗装作業をしている自動車修理工について 健康調查をする機会を得たので,これらの成績について 報告する。

\section{II. 調查対象者}

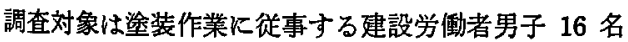
と, 自動車修理工男子 30 名, 対照群として有機溶剤を 报っていない主に事務系の仕事に従事している男子 30 名である。

\footnotetext{
* 東京女子医科大学衛生学公貌衛生学教室

**学働科学研究所 平成 2 年 7 月 11 日受付

* Department of Hygiene and Public Health, Tokyo Women's Medical College

** The Institute for Science of Labor Received for publication, July 11, 1990
}

これらの対象者の年龄，身長などは Table 1 に示すご とくで，各群の平均值に有意差はみられなかった $\left(x^{2}=\right.$ 1.47).

ただ，1日の奥㖶本数は対照群に比べて自動車修理 工，建設労働者の順にやや多かった。

领酒歷は，対照群比ぺて自動車修理工は短く，建設 労働者は長い傾向にあったが，有意差はみられなかった $\left(\chi^{2}=1.93\right)$.

\section{III. 調 查 方 法}

作業条件（曝露防止設備の有無, 使用溶剤名, 溶剤の 用途，作業歷，作業時間）および自覚症状に関する質問 票を用いて調查した。

血液就よび尿を採取し，以下の検查を行った. 血液検 查項目は，赤血球数，白血球数，血色素量，へマトクリ ッ卜值，白血球分画，全血比重，好中球機能椧査として $の$ NBT 還元能試験 (nitroblue tetora-zolium reduction test) 22) である. 血清生化学的検査のうち，GOT, GPT, 総コレステロール(TC), HDL-コレステロール(HDLC), 中性脂肪（TG），低比重りポタンパク (LDL)，超 低比重りポタンパク (VLDL)，カイロミクロン(CM), リン脂質 $(\mathrm{PL})$, 遊離コレステロール(FC), 遊離脂肪 
Table 1. Characteristics of the groups using organic solvents and control group.

\begin{tabular}{|c|c|c|c|c|c|c|}
\hline & \multirow{2}{*}{\multicolumn{2}{|c|}{$\begin{array}{l}\text { Control group } \\
\quad(n=30)\end{array}$}} & \multicolumn{4}{|c|}{ Groups using organic solvents for painting } \\
\hline & & & \multicolumn{2}{|c|}{$\begin{array}{l}\text { Vehicle repairmen } \\
\qquad(n=30)\end{array}$} & \multicolumn{2}{|c|}{$\begin{array}{l}\text { Construction workers } \\
\qquad(n=16)\end{array}$} \\
\hline & Mean & Range & Mean & Range & Mean & Range \\
\hline Age & 33.5 & $21-55$ & 35.4 & $21-61$ & 34.9 & $18-55$ \\
\hline Height $(\mathrm{cm})$ & 169.0 & $160-178$ & 167.8 & $160-178$ & 167.8 & $153-180$ \\
\hline Weight (kg) & 63.2 & $49-74$ & 59.8 & $50-80$ & 62.1 & $50-90$ \\
\hline No. of cigarettes (No./d) & 10.0 & $0-50$ & 12.7 & $0-30$ & 15.2 & $0-40$ \\
\hline Drinking habits (yr) & 10.6 & $0-30$ & 8.6 & $0-25$ & 16.3 & $0-35$ \\
\hline
\end{tabular}

酸 (FFA)，IgG，IgM，IgA はオートアナライザーで 測定し，IgE は RIA 法3で測定した。な打採血は早朝 空腹時とした.

尿検查は，尿タンパク (UP) と㽷ウロビリノーゲン (UG) の定珄試験と，一部の建設労働者については叙装 作業前後の尿を採取し，トルェン，キシレンの尿中代謝 産物を高速液体クロマトグラフィーで測定した. 高速液 体クロマトグラフィーの条件として，カラムはステンレ ス製の $\mu$ Bondapak $\mathrm{C}_{18}$ (Waters 社製)，移動相として， $\mathrm{KH}_{2} \mathrm{PO}_{4}: \mathrm{CH}_{3} \mathrm{OH}: \mathrm{CH}_{3} \mathrm{COOH}(75: 25: 0.2)$ を使用 し, 紫外部 $254 \mathrm{~nm}$ で検出した.

また，使用していたシンナーの含有成分はガスクロマ トグラフィーで測定し，各成分の割合 (W/W\%) を算出 した. ガスクロマトグラフィーの条件として，カラムは

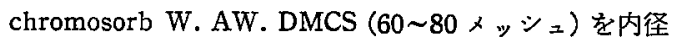
$3 \mathrm{~mm}$ 長さ $3 \mathrm{~m}$ に充填したものを用いた. キャリアー ガスには窒素を用い，流量は毎分 $30 \mathrm{ml}$ とした。.カラム 温度は $60 \sim 150^{\circ} \mathrm{C}$, 試料注入口温度は $150^{\circ} \mathrm{C}$ とし, 検出 器は水素炎イオン化検出器老用いた。

\section{IV. 結果}

\section{1) 作業条件}

作業条件は，Table 2 に示すごとくで，まず建設労働 者についてみると，ビル内での塗装の場合，局所排気装 遖る換気扇も使用せず，ほぼ密閉状態と思われる室内で スプレーガンによる塗装作業を行っていた，また保護具 としての有機ガス用防毒マスクは使用して顷らず，保護 手袋の着用は 5 人に1人くらいで，それす暑さとわずら わしさのためか,すぐにはずしてしまうといら状沉であ った。

これに比して，自動車修理工は局所排気装置や換気扇 のいずれかが設直されているところで作業をするか，ま たは庫外で作業をすることが多く、ほとんとの人が有機
ガス用防毒マスクを着用していた.

濹装歴は自動車修理工が $8.7 \pm 6.1$ 年 (0.9 22.9年)， 建設労働者が $11.0 \pm 8.9$ 年 $(0.8 \sim 30.0$ 年) で後者がや や長期間であるが有意差はみられなかった。しかし，染 装作業に従事している時間が，自動車修理工は 1 週間に 4 24 時間であったのに対し，建設労傎者は 1 週間に 36〜48 時間にもなり，後者の方が長時間であった。

\section{2) 使用溶㓮}

建設労働者が塗料を溶かすために使用していたシンナ -4 種類について，成分を分析してみると，Table 3 K 示す結果となった. すなわち， $\mathrm{A}$ 以外の 3 種類のシンナ 一の主成分はトルェンであり，酭酸エチル，MIBK, IPA なども検出された. したがって，作業者は塗装中， これらの混合有機溶剤に瀑露されていたことになる.

\section{3 ）尿中代謝産物の定量}

今回の調查では, 16 人の建設労働者の中から 7 人につ いて作業前後の尿を各 1 回だけ採取し、トルエンの尿中 代謝産物である馬尿酸と，キシレンの尿中代謝産物であ るメキル馬尿酸を分析した結果を Fig.1 に示した. 馬尿 酸濃度の変化をみると 7 名のうち 3 名は作業前から刘照 群の平均值 $(300.1 \pm 184.0 \mu \mathrm{g} / \mathrm{ml})$ 以上の高值を示し, この中の 1 名は $1,099.6 \mu \mathrm{g} / \mathrm{ml}$ の高値を示した. そし て，塗装終了後に急增した者が 4 名，やや増加した者が 3 名あり，平均すると約 4 倍増加していた。 またキシレ ンの尿中代謝産物であるメチル馬尿酸濃度は，対照群は 定量限界以下であるのに対し，塗装作業者の前値は平均 $17.4 \mu \mathrm{g} / \mathrm{ml}$ ，作業後になると $121.0 \mu \mathrm{g} / \mathrm{ml}$ と 10 倍近 い上昇を示した。

\section{4) 自喾症状}

自覚昰状は，全項目を通して有訴率は建設労働者に多 く，特に，『醉った感じ』の訴克が，対照群が $0 \%$ ，自 動車修理工が $10.0 \%$ に対し，建設労働者が $81.3 \%$ であ った. 
Table 2. Working conditions of vehicle repairmen and construction workers.

\begin{tabular}{|c|c|c|}
\hline & $\begin{array}{l}\text { Vehicle repairmen } \\
\qquad(n=30)\end{array}$ & $\begin{array}{c}\text { Construction } \\
\text { workers }(n=16)\end{array}$ \\
\hline \multicolumn{3}{|l|}{ Preventive device } \\
\hline Closed equipment & $23.3 \%$ & $0 \%$ \\
\hline Local air exhaust & $20.0 \%$ & $0 \%$ \\
\hline Ventilator & $56.7 \%$ & $0 \%$ \\
\hline \multicolumn{3}{|l|}{ Protective tools } \\
\hline Mask & $0 \%$ & $0 \%$ \\
\hline Respirator for organic solvents & $93.3 \%$ & $0 \%$ \\
\hline Protective clothing & $0.3 \%$ & $0 \%$ \\
\hline Protective gloves & $66.7 \%$ & $18.8 \%$ \\
\hline Use of organic solvents & Painting $\cdot$ Washing & Painting $\cdot$ Washing \\
\hline \multirow[t]{5}{*}{ Constituent of solvents } & Toluene & Toluene \\
\hline & Xylene & Xylene \\
\hline & Chloroform & MIBK \\
\hline & Trichloroethylene & IPA \\
\hline & & Ethyl acetate \\
\hline Period engaged in painting (yr) & $8.7 \pm 6.1$ & $11.0 \pm 8.9$ \\
\hline Hours engaged in painting ( $h / w k)$ & $4-24$ & $36-48$ \\
\hline
\end{tabular}

Table 3. Constituents of four kinds of paint thinners (W/W\%).

\begin{tabular}{cccccccccc}
\hline & $\begin{array}{c}\text { Ethyl } \\
\text { acetate }\end{array}$ & $\begin{array}{c}\text { Isobutyl } \\
\text { ketone }\end{array}$ & IPA & MiBK & Toluene & $\begin{array}{c}\text { Isobutyl } \\
\text { alcohol }\end{array}$ & $\begin{array}{c}\text { Ethylene } \\
\text { glycol } \\
\text { monobutyl } \\
\text { ether }\end{array}$ & $\begin{array}{c}\text { Mineral } \\
\text { spirit }\end{array}$ & $\begin{array}{c}\text { Unknown } \\
\text { composi- } \\
\text { tion }\end{array}$ \\
\hline A & - & - & - & - & - & - & - & 100.0 & - \\
B & 15.0 & - & - & 10.0 & 63.5 & 6.0 & 5.0 & - & - \\
C & 8.3 & 9.9 & - & 4.8 & 59.3 & - & - & - & 17.7 \\
D & - & - & 46.3 & - & 53.0 & - & - & - & - \\
\hline
\end{tabular}

また，『熏，咽喉への刺激感』は，建設労働者と自動 車修理工は，それぞれ $50.0 \%$ と $26.7 \%$,『頭重感』が $25.0 \%$ と $16.6 \%$ ，『悪心・嘔吐』が $25.0 \%$ と $23.3 \%$,

『易疲労』が $25.0 \%$ と $23.3 \%$ であった.

なお，対照群は，上記のほとんどの質問事項に対し， 有訴察が 0 〜数\%であった.

\section{5) 血㳸検查}

血液検查結果を, 対照群, 自動車修理工, 建設労働者 の3 群について比較してみると, 赤血球数，白血球数， $\mathrm{Ht}$ 值， $\mathrm{Hb}$ 量は， 3 群とすほぼ同じレベルで有意差は みられなかった。

しかし，好酸球は自動車修理工が $3.3 \pm 2.4 \%$ で, 対 照群 $(2.2 \pm 1.4 \%)$ に比して有意 $(p<0.05)$ 飞増加し
ており，また建設労㗢者は $3.6 \pm 3.6 \%$ で平均值は增加 していたが有意差はみられなかった。そと他の分画で注 目されたのは，建設労働者に好中球の桿状核が 3.7\% み られ，対照群 (1.7\%)，自動車修理工（1.6\%) との間 に有意差 $(p<0.005)$ がみられた。したがって核形移動 指数 (Kothe 指数) も建設学働者で 6.3 となり，核の 左方移動があった：しかし，これ以外に，好中球・リン パ球比である N/L 比などの白血球分画には注目すべき 変化はみられなかった。

次に NBT 還元能試験の結果をみると, Fig.2 に示す ごとく，対照群が平均 33.5 $12.0 \%$ であるのに比し， 自動車修理工では $32.9 \pm 8.3 \%$ で両群間に有意差はみら れなかったが，建設労働者では: 19.8土16.1\% と対照群 

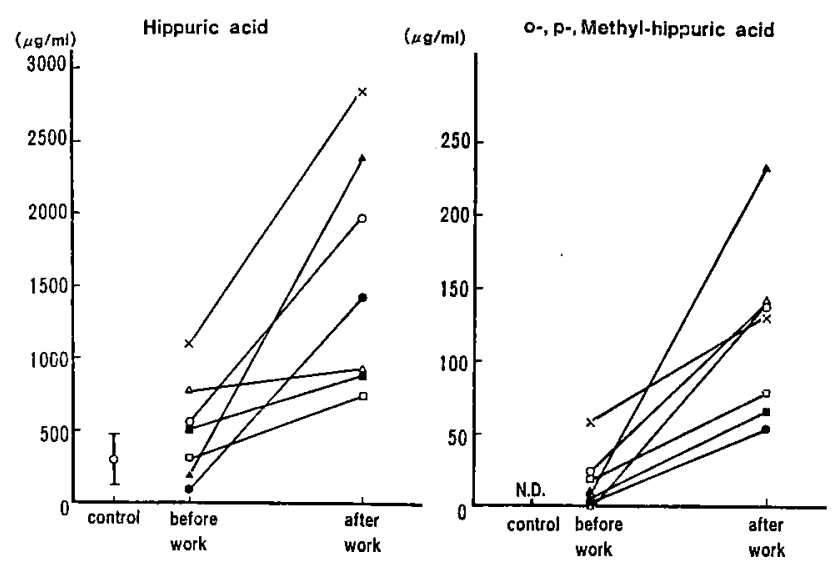

Fig. 1. Concentrations of urinary hippuric acid and $o-, t$-methyl hippuric acid before and after work.

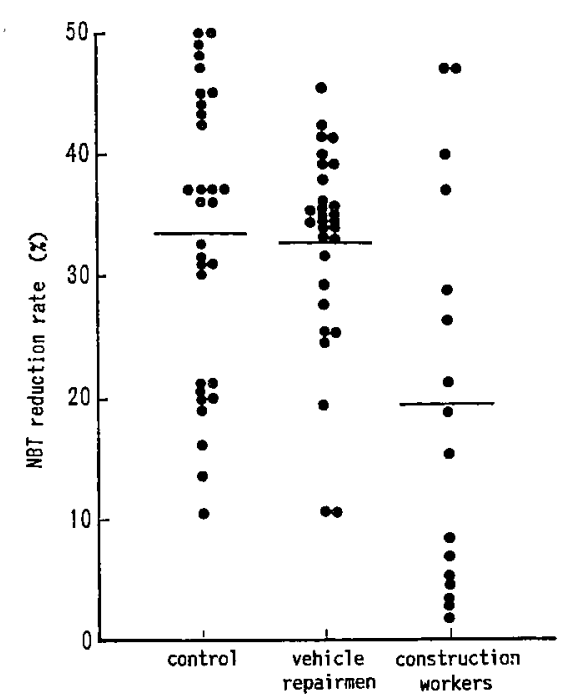

Fig. 2. NBT reduction rate of neutrophils among control groups, vehicle repairmen and construction workers.

に比し有意 $(p<0.05)$ に低く，機能の低下が認められ た.

\section{6) 血清生化学検查}

Fig.3 の左側には, 全血比重 (Gb), 赤血球数 (RBC), 尿タンパク (UP)，尿ウロビリノーゲン (UG), GOT, GPT の結果执よび改正前の有機溶剂中毒予防規則に基 つく判定基準4,5)で異常値を示した者の割合を図示した。 自動車修理工および建設労動者の 3.3 6.7\% K異常値 を示す者がみられたにすぎなかった. 次に Fig.3 の右側 に示した血清生化学検查結果, TC, HDL-C, TG, LDL,
VLDL， CM， PL，FC，FFA，IgE の異常率をみると， いずれの項目も建設作業者に高率にみられた。

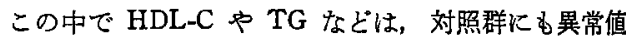
を示す例がみられたが，その他の項目，特に VLDLゃ $\mathrm{CM}, \mathrm{PL}$ ，IgE などの異常は建設労働者に高率であっ た.

また, Table 4 は各免疫グロブリンの值を示したむの で，IgG，IgM，IgA 值は各群で有意差はみられなかっ たが, IgE 值は, 対照群が $95.2 \mathrm{IU}$ ，自動車修理工は

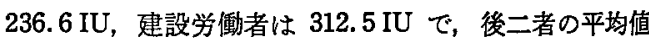
は高値を示し，建設労働者では対照群との間に有意差 $(p<0.005)$ がみられた.

\section{V. 考 察}

某建設会社の下請け作業者で，換気の悪い建造物の内 部で，保護具の装着すせずに塗装作業をしていた建設労 働者と，環境条件の比較的整備されている自動車修理工 について，血液検査などを行い，有機溶㶡の生体影響を 検討した.

両群の使用していたシンナ一の成分は 5〜6種類の有 機溶剤からなる混合溶剂からなり，主成分はトルェンで あった。

建設労働者は，これらの混合溶剤と塗料を泥和して調 製したものをスプレーガンに入れて吹き付ける作業をし ていて，換気の覀い空間はたちまち塗料のミストで前方 がみえなくなるほどであった。このような環境下で作業 をしていたためか，『鼻，咽頭への刺激感』や『醉った 感し』の有訴率が高くみられた。しかし，同じ塗装作業 をしていてもダクトや換気扇の設置下で作業している自 


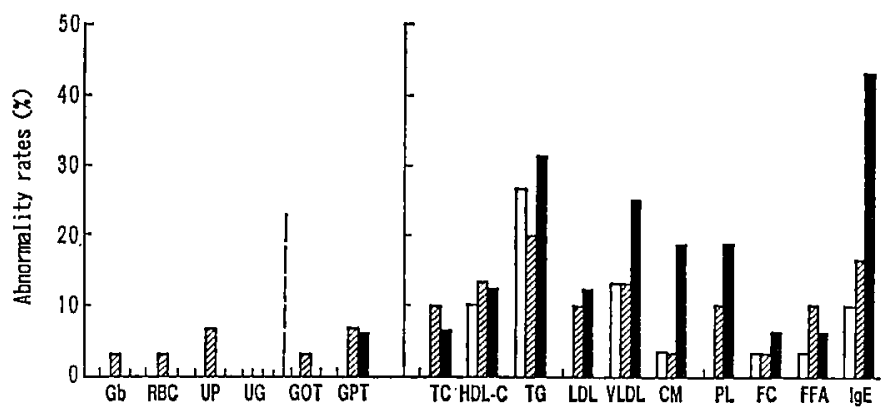

Fig.3. Abnormality rates for blood examinations among control group, vehicle repairmen and construction workers. Vehicle repairmen, Construction workers.

Table 4. Immunoglobulin levels among the three groups.

\begin{tabular}{lccc}
\hline & $\begin{array}{c}\text { Control group } \\
(n=30)\end{array}$ & $\begin{array}{c}\text { Vehicle repairmen } \\
(n=30)\end{array}$ & $\begin{array}{c}\text { Construction } \\
\text { workers }(n=16)\end{array}$ \\
\hline IgG $(\mathrm{mg} / \mathrm{dl})$ & $1,227.0 \pm 210.2$ & $1,325.0 \pm 256.1$ & $1,279.0 \pm 239.4$ \\
IgM $(\mathrm{mg} / \mathrm{dl})$ & $123.3 \pm 51.2$ & $121.9 \pm 52.8$ & $144.0 \pm 44.7$ \\
IgA $(\mathrm{mg} / \mathrm{dl})$ & $230.5 \pm 92.8$ & $217.7 \pm 83.9$ & $244.1 \pm 95.5$ \\
IgE (IU) & $95.2 \pm 135.3$ & $236.6 \pm 438.0$ & $312.5 \pm 316.9^{*}$ \\
\hline
\end{tabular}

* $p<0.005$ as compared with the control group.

動車修理工の有訴率は, 10 26.7\% であった.

建設労働者の尿中のトルエン, キシレンの代謝産物を 分析してみると， 7 例中 4 例が作業後に急増し，その中 の 1 例は作業前値がすでに $1,000 \mu \mathrm{g} / \mathrm{ml}$ を越えていた. つまり, 前日の瀑露がいか滈濃度であったかが推測さ れた. 事実, 尿中馬尿酸濃度から気中トルェン濃度を推 定6,クしてみても平均で $41 \mathrm{ppm}$ ，最高で $118 \mathrm{ppm}$ 程度 のトルェンに懪露された可能性がある. 検知管による作 㘹棵境中のトルェンの測定です1110 ppm が湘定された. また，キシレンの代謝産物であるメチル馬尿酸る同じ㑯 向で, 対照群では定量限界以下でめったのに対し, 建設 労働者は前値で $50 \mu \mathrm{g} / \mathrm{ml}$ 以上も検出された例があり, 作業後には $200 \mu \mathrm{g} / \mathrm{ml}$ 以上を示していた. この作業者 たちは作業終了後, 顔や手についた塗料をおとすために バケッなどにシンナーを入れ洗っていたので，経皮吸収 も無視しえないと思われた。

また，赤血球数， $\mathrm{Hb}$ 量， $\mathrm{Ht}$ 值，白血球数などは， 対照群とほぼ同じレベルで有意差はみられなかったが， 白血球の分画像をみるとばらつきは大きいが，建設労働 者, 自動車修理工の両群ともに好酸球がやや高い傾向を 示していた。 これと似た現象を竹内ら8 は,トルエンに 連続懪露させたラットについてみいだし，好酸球が増加
した後に減少したことを報告している.

また，Greenburg らすは，トルェン慢性中毒患者のり ンパ球が増多していることを報告しているが，我々の調 查結果では $\mathrm{N} / \mathrm{L}$ 比には変化はみられなかった。

また好中球の核分画をみると，建設労働者の場合，桿 状核が 3.7\% と多く，対照群との間に有意差（ $p<$ 0.005）が双られ，核の左方移動がみられた。このよう に，白血球数が特に増加していないのに，なぜ核の左方 移動のような現象がみられたかは明らかではないが，好 中球に何らかの機能変化が起こっているのではないかと 思われた。

好中球は，微生物や異物乞の他を貪食して生体防御作 用があるが，その中には賣食したるのを殺菌処理する力 の強いものと弱いものがある.この殺菌貪食能の強弱を 知る一つの方法として NBT 還元能試験 ${ }^{2}$ がある.

そこで, 有機溶剤曝露の白血球貪食能への影響を調べ るため, NBT 還元能試験を行った. その結果, 建設労 働者の還元能の平均値は $19.8 \%$ で，対照群の $33.5 \%$ に 比して有意 $(p<0.005)$ に低値を示した. さらに, $10 \%$ 以下の低值を示す例が対照群や自動車修理工にはみられ なかったのに比し，建設労働者の場合は 16 例中 7 例 (43.8\%) みいだされた。つま，高濃度の有機溶剂に 
絽り返し曝露されると，白血球数は減少していないの に，貪食能は有意に低下しているという結果が示され た. Bansagi 10) けトルエンに曝露されていたプリント作 業者の白血球貪食能が低下していたことを報告し，松下 ら を検查し，フセトン単一䀧露においても著明な貪食能の 低下が起こることをみいたしている，また，Moszczynski ら ${ }^{12)}$ は，ベンゼン，トルニン，キシレンなどを 含も有機溶剤取扱い者について，その暴露 (労働) 期間 とNBT 還元能試験との関係を観察し，有機溶剂曝露の 初期の段階では適応が生じ NBT 還元能は增加するが, 長期間の懪露になると，逆に好中球の機能低下が起こる ことを示唆している.

血清の生化学的検查結果をみると，GOT，GPT など に異常值を示主例は少なかったが, VLDLや LDL, CM，PL などに高值を示す例が建設労働者に多いのが 注目された。この理由は明らかではないが，緒方ら13) は,トルエンが、CM，ついでリポ蛋白に結合すると報告 し，トルェンが体内でこれらの脂質に何らかの影響を与 えていることが推測された. 免疫グロブリンの值は, IgG, IgM, IgA などは対照群との間に差はみられなか ったが，IgE 值は建設労衝者と自動車修理工に高值で, 特に建設労働者の值は対照群の 3 倍以上の高值を示して いた. これら両作業者は, ウレタン系の塗料す使用して おり，硬化剂としてイソシアネート化合物である hexamethylene diisocyanate が浘和されているので，その影

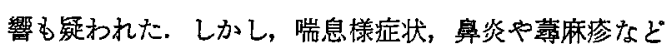
を示す者はみられなかった。

以上，某建設会社の塗装下請け作業者の健康調査を実 施した結果, 血清リン脂質やリポ蛋白分画の增加, IgEの 増加，好中球機能が低下していることを証明した。これ らの所見とシンナーを含さ塗料への曝露との因果関係,
さらに，もし因果関係がある場合はこのよらな所見が持 続した場合どのよらな疾患が発生してくるのかに関して も，今後検討していく必要があると思われる。

健康調㭗票に関してここ協力臷きさした神奈川県予防医学協 会に感謝申し上げます。

$$
\text { 文献 }
$$

1）山口 裕. シンポジム 1 建設業について. 産業医学. $1989 ; 31: 529$.

2）金井 泉. 臨床険㚗法提要. 東京：金原出版，1983： 268-269.

3) 四宮敬介. Radioallergosorbent test (RAST) Kよる アレルギー診断法. 最新医学 $1975 ； 30: 2213-2228$.

4) 有機溶剂中䇘予防規則第29条.

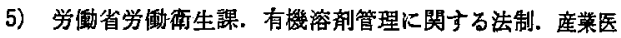
学シャーナル $1985 ; 8: 5-15$.

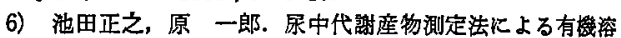
都儤露の評価. 産業医学 $1980 ; 22: 3-17$.

7) 緒方正名, 武田和久. 工業化学物質のとトに和ける生物 学的モニタリング. 東京 : 同文書院, $1987:$ 98-106.

8) 竹内康浩, 田中豊䅹, 松本忠雄, ほか。トルンン曝露時

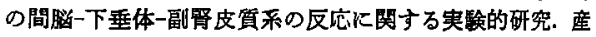
業医学 $1972 ; 14: 543-553$.

9) Greenburg $L$, Mayers $M$, Heimann $H$, et al. The effects of exposure to toluene in industry. $J$ Am Med Assoc 1942 ; 118 : 573-578.

10) Bansagi J. Effect of toluene on the phagocytic activity of white blood cells in printers. Mun. kavedelem $1968 ; 14: 26-28$.

11）松下敏夫，吉宗絢子, 井上俊，ほ加、フセトンの許容 漕度決定に関する実験的研究. 産業医学 $1969 ; 11: 477-$ 485.

12) Moszczynski P, Lisiewicz J. Nitrotetra zolium blue (NBT) reduction and the time of occupational exposure to benzene and its homologues. Haematologica $1983 ; 68: 689-693$.

13）緒方正名. 有機溶剂取り级い者の健康管理. 座業医学引 ヤーナル 1985; 8:4-18.

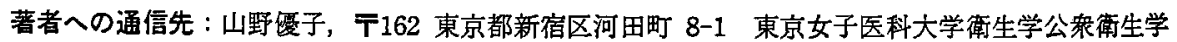
教室 Reprint requests to Department of Hygiene and Public Health, Tokyo Women's Medical College, 8-1 Kawada-cho, Shinjuku-ku, Tokyo, 162 Japan (Y. Yamano) 